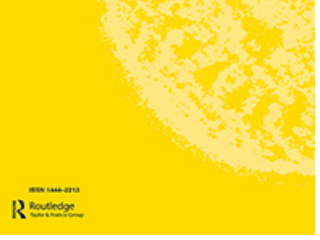

\title{
‘No Nation of Experts': Kustom Tattooing and the Middle-Class Body in Post-Authoritarian Indonesia
}

\section{Benjamin Hegarty}

To cite this article: Benjamin Hegarty (2017) 'No Nation of Experts': Kustom Tattooing and the Middle-Class Body in Post-Authoritarian Indonesia, The Asia Pacific Journal of Anthropology, 18:2, 135-148, DOI: $10.1080 / 14442213.2016 .1269833$

To link to this article: http://dx.doi.org/10.1080/14442213.2016.1269833

册Published online: 19 Feb 2017.

Submit your article to this journal $\square$

Џ Article views: 29

Q View related articles $\circlearrowright$

View Crossmark data ¿ 


\section{'No Nation of Experts': Kustom Tattooing and the Middle-Class Body in Post-Authoritarian Indonesia} Benjamin Hegarty

Tattooing among young middle-class people in Indonesia has increased noticeably since the late 2000s. I draw on ethnographic research in tattoo studios alongside interviews and magazine sources to locate the style known as kustom within its social and cultural context. I describe how kustom tattooing is the product of patterns of consumption centred on the body, drawing resources from a globalised, mass mediasaturated environment. Indeed, consumers describe it as an important avenue for self-expression. By contrast, tattooists and those inside the scene describe kustom as a way of transcending geographical markers of identity: to be 'anything and everything'. This article explores this tension between self-expression and the political aims of kustom. Kustom tattooing is also novel by virtue of its absolute emphasis on 'no expertise'. It thus exposes a space where the stress on expertise and selfimprovement, which characterises middle-class cultures in post-authoritarian Indonesia, gives way to creative and hybrid articulations of identity.

Keywords: Tattoo; Kustom; Youth Culture; Masculinity; Indonesia; Globalisation

Tattooing has undergone remarkable growth in Indonesia since the early 2010s. Small, clean tattoo studios can now be observed in the fashionable areas of small and large cities alike throughout the islands of Java, Bali and Sumatra. Tattoos are flaunted by media celebrities and, controversially, a government minister appointed in $2014 .^{1}$ In a short period of time, large numbers of young middle-class people, particularly in urban settings, have come to embrace tattooing as an avenue for self-expression. Although there are no published statistics available, Indonesia probably has the

Benjamin Hegarty is a PhD Candidate in Anthropology, School of Archaeology and Anthropology, Australian National University. Correspondence to: Benjamin Hegarty, School of Archaeology and Anthropology, College of Arts and Social Sciences, Australian National University ACTON 0200 ACT Australia. Email: benjamin. hegarty@anu.edu.au 
largest number of practising tattooists in Southeast Asia. ${ }^{2}$ The increased visibility of tattoos and tattooing over the past decade has taken place in the context of widespread transformations of growing consumerism and mass media. This has also been accompanied by the emergence of heterogeneous spaces for body-centred consumption and pleasure including barbershops, cafés and tattoo studios-a globalised 'hipster' culture inspired by transnational trends. These spaces for consumption are often located close to each other in fashionable areas of cities and towns.

This article focuses on tattooists who refer to their practice as kustom and to a lesser degree their customers. ${ }^{3}$ Kustom is a term used by tattooists and enthusiasts, but also refers to a community (komunitas) dedicated to customising motorbikes and cars. Kustom, as used by Indonesian tattooists, describes control over a tattoo's modification and the creative process even though images may be drawn from pre-existing sources. This, they say, contrasts with tattoos that are 'ready-made' or 'mass produced'. Kustom is most popular in urban centres throughout Indonesia, as advertisements and articles in the Bali-based Magic Ink tattoo magazine indicate. While most enthusiasts reside in large cities such as Jakarta, Bandung, Yogyakarta, Surabaya and the southern part of the island of Bali, kustom tattooists also work in smaller cities on the islands of Sumatra, Sulawesi and even Papua. Spaces of aesthetic modification such as salons (Boellstorff 2007, 93) and photo studios (Strassler 2010) have long been sites for fashioning the self into an ideal Indonesian subject. While the authoritarian New Order regime (1966-98) led by President Suharto stressed a homogenous ideal of national identity, post-authoritarian Indonesia is made up of 'fascinating blends and dangerous tensions' (Heryanto 2008, 9). More recently, tattoo studios have appeared alongside salons and photo studios. While salons, for example, operated to produce 'better representations of Indonesian womanhood and manhood' (Boellstorff 2007, 111) tattoo studios give rise to other manifestations of identity and self-expression.

The centrality of the body to self-expression - the focus of this article-is further evidence of a shift towards the 'conjunction of a fashioned self with middle-class consumerism' (Boellstorff 2005, 119). Scholars have recently commented on the widespread emergence of a middle-class culture informed by Islamic morality and a related emphasis on bodily purity and polished femininity (Jones 2010a; Brenner 2011). Given that burden of expertise has been borne by women in Indonesia, femininity has understandably been the dominant site for observing these changes. While not exclusively practised by men, tattooing provides other insights into this process given that it is a masculine domain that draws on ideals of rebellion and naughtiness as part of its appeal. I argue that the consumers of kustom tattooing understand it in a similar way to the young, female participants of self-improvement courses in Yogyakarta described by Jones (2010b). Through kustom tattoos too, 'the self can be turned into an object of analysis, both as a physical body and as an individual personality' (Jones 2010b, 270). Kustom differs from other forms of body modification and improvement because it eschews the stress on expertise integral to mostly feminine practices of self-improvement in post-authoritarian Indonesia (Jones 2010b). In line with its historical association with crime in Indonesia, tattooists stress that a lack of expertise or central authority is a 
defining characteristic of their practice. The growing popularity of tattooing in Indonesia -including among women-makes kustom a particularly fascinating site for understanding shifting ideals of self-expression among young middle-class consumers.

More specifically, kustom tattooing is consistent within a broader popularity of doit-yourself (DIY) aesthetics in urban Indonesia in fashion (Luvaas 2010) and music (Baulch 2007). Tattooists are thus similar to Bandung fashion designers described by Luvaas $(2010,1)$ who 'construct a diverse, even contradictory, set of associations and imagery that have become representative of a transnational youth culture'. Throughout this article I define 'middle class' with reference to Baulch (2007) and Heryanto (1999) who argue that changing formulations of power in Indonesia are reflected in new forms of conspicuous consumption linked to self-expression: an effort to 'build a new bourgeois hegemony through culturalization' (Heryanto 1999, 162). Both the tattooists and consumers I spoke to are mostly university-educated or university-enrolled young people, born after 1980. I refer to 'consumers' to indicate a group who obtain tattoos as an aesthetic choice structured by a desire for selfexpression, rather than claiming membership of a particular subcultural identity. However, while notions of self-improvement articulate long-established cultural values in Indonesia, tattooing has until recently been a severely stigmatised practice. Given this rapid move from stigmatised to popular and commercialised status, tattooists and consumers adeptly negotiate the meaning of the practice in strategic ways.

In defining the 'social skin', Turner $(2012,486)$ refers to 'the surface of the body ... not only as the boundary of the individual as a biological and psychological entity but as the frontier of the social self as well'. Following Turner (2012), this article argues that kustom tattooing must be understood according to dominant middle-class culture rather than as a concerted resistance against it. In this regard, the combination of values of individualism and transnational aesthetics of kustom tattoos might give the impression that young middle-class Indonesians slavishly accept global trends. However, ethnographic research reveals that the aesthetic that tattooists and their consumers desire must be situated within Indonesia's post-authoritarian present and the recent authoritarian past. While consumers might describe their tattoos as art (seni) to distance themselves from a historical connotation of criminality, tattooists are less willing to accept this designation. Their stress on tattooing as a form of labourwith modification (dimodifikasi) as its central characteristic-instead reveals a disavowal of dominant cultures of expertise in post-authoritarian Indonesia. In this regard, tattooists see themselves as modifying the 'social skin' (Turner 2012) of middle-class Indonesia, not as experts, but as active 'customisers' of a globalised world.

\section{Method and Context}

This article is based on participant observation and interviews conducted between late November 2014 and late January 2015 with five tattooists and others working in the kustom scene in the city of Yogyakarta in the central part of the island of Java. This fieldwork supplemented preliminary research undertaken in 2010. I conducted 
participant observation at two studios with which I had a close relationship on a weekly basis during the period outlined above. However, I had trouble in locating the tattoo studio as a bounded site for the production of culture. Following DeMello $(2000,18)$, I found that the 'notion of community was not being defined exclusively in the tattoo shop, but was a more fluid notion, one that takes shape in the realm of discourse'. I thus draw on sources from the Bali-based, nationally distributed tattoo magazine Magic Ink in order to expand on my ethnographic research. I also met with and interviewed other people active within kustom culture, usually at their tattoo studios or at events; social settings that opened late into the evening. I attended the annual Kustom Fair in Yogyakarta in September 2014 and visited a tattoo studio in Ubud, Bali in December 2014. The type of data collected and my focus is indicative of my interest in the relationship between tattooists and the consumers of tattoos. Interviews supplemented participant observation at studios and provided a level of detail necessary for defining kustom. Participant observation allowed me to understand tensions and contradictions in people's understandings of tattooing, as well as to understand it as a growing trend related to self-expression. While the small number of informants and focus on Java and Bali is limited in scope, the research is useful in suggesting future avenues for exploration.

Recent research on globalisation and identity in Indonesia has described tattooing in passing, most prominently as one marker of 'the West' for followers of punk (Baulch 2007) and metal (Martin-Iverson 2014). This research describes how Indonesian youth culture interacts with global trends, asserting young peoples' desires for selfexpression and participation in transnational movements, while locating them within a distinctive subcultural group. Baulch $(2007,2)$ observes that alternative musicians 'defined their underground in opposition to music television and major recording labels'. By contrast, the tattooists I spoke with did not necessarily stress participation in such underground spaces, although their social worlds overlapped with those based on punk and rock music. This is reminiscent of transformations that date back to as early as the mid-1990s, when the media began to present alternative music fandom as including 'growing numbers of young, metropolitan, bourgeois men and women and their transnational consumerist aspirations' (Baulch 2007, 16). However, tattoos do not globalise in the same way as alternative music; this is primarily because they require tattooists with a certain level of ability, as well as consumers willing to have their body permanently altered. Kustom's popularity among middle-class consumers, including women, reflects recent transformations in how 'the ideal Indonesian citizen is constituted through exposure to images which promote and celebrate consumerism' (Baulch 2007, 25). However, tattooists and consumers only rarely described their understanding of tattoos through its relationship to consumption or national identity. Tattooists' interactions with consumers and consumerism reveal how transnational aesthetics make possible new dynamics of self-expression and individuality.

What makes this transformation particularly notable in Indonesia is that tattoos have been subject to an enormous amount of stigma for their association with criminality (kriminalitas). Indonesia's authoritarian, military-backed regime deployed the 
figure of the tattooed criminal as the opposite of the normative, obedient citizen (Siegel 1998). The gruesome appearance of possibly thousands of tattooed corpses on street corners between 1983 and 1985 became known as the 'mysterious killings' (penembakan misterius) (van der Kroef 1985). The danger was such that some tattooists even shifted to cosmetic or make-up tattoo practice from this period onwards (Magic Ink 2011a). For these and other reasons, tattoos are understood to be incompatible with hegemonic ideals of bodily comportment. The popular practice of tattooing in Indonesia thus reflects a process of incorporating stigmatised cultural practices, which signify class and ethnic difference, into middle-class culture.

In the United States, the process of recuperating tattooing into white, middle-class cultures erased the working-class and ethnically distinct origins of tattoos, reorienting tattoo practice towards a middle-class notion of the self (Rosenblatt 1997; DeMello 2000). DeMello (2000, 182-183) describes this shift in tattooing in terms of a 'refined image of the middle-class body, which, even when tattooed, is elegant and disciplined'. This has parallels with the Indonesian context, where the gentrification of tattoos reflects a reconfiguration of the relationship between body modification and class. In Indonesia, however, the incorporation of tattooing as a mode of self-expression relies less on a fetishisation of its working-class roots than its disavowal. Kustom tattooists and consumers stressed some distance between their tattoo practices and historic connotations of criminality. This difference was expressed in terms of the relationship between kustom and transnational tattoo practices and styles. For example, one young student in Yogyakarta explained to me that his tattoos were not 'gangster' (preman) or 'village' (kampungan) - both representative of lower-class status-but as the product of an urban, cosmopolitan tattoo studio which is clean and modern. Although tattoos that fetishise ethnic difference are relatively rare, consumers of this type of tattoo celebrated them as a distinctly 'Indonesian' form of tattooing. ${ }^{4}$

By approaching it in terms of broader logics of self-expression and self-fashioning, I place some analytic distance from kustom tattooing as a rejection of dominant understandings or as a resistance to the status quo. Rather than expressing resistance, tattooists and consumers are 'trying to assert some degree of direct control over the new commercial world they live in' (Luvaas 2010, 13). The transnational aesthetic of kustom offers a way for young people to express themselves through a medium other than national identity, while also shunning the more recent stress on self-improvement through expert knowledge that permeates cultural life in post-authoritarian Indonesia (Jones 2010b).

\section{Kustom Tattooing and Identity}

The inaugural 2012 'Kustom Fest' in Yogyakarta attracted approximately 12,000 people, and has since been held annually at a large convention centre in the city (Magic Ink 2012). When I attended in September 2014, 'Kustom Fest' included a large section of about fifteen tattooists, busily tattooing young women and men throughout the event. Tattooing was a prominent feature, taking up the entire set of stalls visible 
from the main hall. Tattooing features prominently on the program, listed under 'body modification'. However, the event dedicated mostly to customised motorbikes, bicycles and cars, modified following an aesthetic that appeared to be derived from a nostalgia for 1950s Americana. As I walked through the bright lights and stands, hip young Indonesians lit cigarettes and pointed out their favourite modified motorbikes or chatted about their latest tattoos. Tattooing could not seem further away from its dangerous association with mysterious killings and phantoms of criminality of the 1980s.

The logos and branding of major cigarette and motorbike companies that covered the fair's central stage reflected the relationship between kustom and consumption. The 25,000Rp (US\$2.40) admission fee was also considered expensive, especially by my younger friends. Furthermore, the tattooists at the show-well known and skilfulwere considered expensive by Indonesian standards. It was based on these observations that I first sensed that kustom gentrifies tattooing and makes it palatable for middleclass consumers. Yet, kustom is fascinating precisely because it integrates logics of individualism and opposition to authoritarianism and top-down expertise. Its image as a practice related to rebellious masculinity is part of its allure, giving rise to a certain anti-authoritarian sentiment. Furthermore, discussion with tattooists and enthusiasts revealed it to be neither completely dominated by consumerism, nor indebted to it for its survival. Tattooists described kustom as resistant to gentrification by virtue of the constant traffic between national and transnational ideas that it requires. Kustom thus forms part of an ambiguous landscape linked to a lingering distrust of authority.

This is reflected in the way that tattooists describe kustom as 'anything and everything', a nebulous and ambivalent style that resists classification. This was also echoed by Huhum, a tattoo enthusiast and central figure in the Yogyakarta kustom scene. He defines kustom as an openness to globalised culture and its customisation. He is also one of its more politically minded participants. 'Kustom is a way for us to explore our identity, without being shackled [kunkung] by paradigms and borders', he explained, referring to kustom's capacity for social change. While Huhum refers to kustom as the appropriation of various styles of dress and culture from an imagined West, it also has a specific Indonesian history rooted in political struggle. He said:

Kustom attacks [serang] constantly. It fights/battles [melawan]. It is a phenomenon that is always renewing itself [di perbarui]. Its very nature itself is kustom. It has no rules, it battles against norms [melawan penam].

Statements such as this reveal kustom as both stemming from a history of authoritarianism and out of the desire to challenge it. It is the very openness of a combination of styles, matched with the ability to fulfil desires for unique self-expression, which make tattoos kustom.

Consumers link tattoos with the expression of various identities. For example, one young man described the incorporation of modified traditional designs with reference to his ethnic identity. 'My father is from Padang', he explained, pointing to his new tattoo which combined motifs from Borneo and Mentawai (an island off the western coast of Sumatra), 'and the islands of Borneo and Sumatra were once 
connected. We're related, you see'. Tattooists also emphasised this flexibility. 'Given that nothing is really authentic anyway', one recounted in Yogyakarta, 'there is no need to worry about correct and incorrect designs'. In this way, both tattooists and consumers praised kustom's adaptability. Indeed, while enjoying the flexibility of styles that kustom makes available, consumers stress its relationship to their own life history. Echoing this sentiment, the founder of Java Tattoo Club, Athonk Sapto Raharjo, contrasts the current possibilities offered by kustom with restrictions imposed by ideals of national identity: 'under Suharto everything had to be the same and one colour, in the name of the oneness of the nation' (Magic Ink 2011b, 10). The authoritarian-era stress on a singular national identity and the stress on expertise directed at self-improvement in post-authoritarian Indonesia is precisely what practitioners of kustom seek to avoid.

Indeed, this lack of expertise was emphasised by each of the tattooists with whom I spoke. In describing their work as kustom, they shared a general opinion that it was limited only by the freedom expressed in selecting a certain style. '[My style is] definitely kustom', well-known Yogyakarta tattooist Kampret explained to me, 'I take a lot of different styles and I use them'. When I asked him how it might relate to a distinctly 'Indonesian' style, he explained that while Indonesian tattooing cultures exist, these are not a part of kustom culture, as they form part of a singular or authentic tattoo aesthetic. 'These are probably the only real authentic [asli] tattoos in Indonesia', he said. Hesitating, he continued, 'But even this is probably customised [dikustom] to a degree', revealing the plasticity of kustom as a category that might refer to 'anything and everything'.

Kustom is also defined by economic dimensions. For instance, the work of senior tattooist Sono is relatively expensive, with one tattoo costing in the order of hundreds of dollars. He works full time as a tattooist, manages a studio in Ubud and frequently travels abroad for tattoo-related events. He has an international reputation and is popular among tourists. Sono described kustom as traditional culture applied to something modern. I met with him at his tattoo studio in Ubud, overlooking the expansive rice fields that surround the town. As is common to high-profile tattoo studios in Bali, he receives a combination of Western and Indonesian customers. He explained to me that he always takes a traditional Indonesian motif and draws on 'modern' experiences. This process, he said, results in kustom:

I'm not really sure about the beginnings of kustom. What I do know is that kustom can also be used by many people and in various ways, and their concept might become a new style but people will always know that the kustom style is inspired by traditional culture.

Sono described kustom as a way to maintain a connection to indigenous tattoo cultures, diffuse and unrelated to the original as it may be. He expressed pride in sustaining a culture that is Indonesian, or at least a DIY version of tattoo cultures that are indigenous to the archipelago. It is not necessarily authenticity that customers or Sono seek. Rather, he said, the tattoos that he ends up creating are derived from a mix of his interests and consumers' desire for self-expression. 
I have described how kustom reflects emergent concerns for identity and selfexpression. Kustom tattooists in Indonesia seek to avoid copying; rather, they seek something new in the very act of modifying. This is so even when they draw on a visual vocabulary derived from transnational tattoo cultures. While borrowing and modifying a design is acceptable, this should be done with reference to a specific customer's desires for self-expression. I explore this relationship between consumers' desire for self-expression and tattooists' emphasis on customisation in the following two sections. I do so by focusing on kustom's relationship to class and gender respectively.

\section{The 'Artist' and the 'Handyman'}

Located on a dusty highway on the outskirts of Yogyakarta, the tattoo studio I visited most often is representative of those frequented by the largest group of consumers of kustom. In Yogyakarta this includes a very large population of middle-class students who travel from around Indonesia to study at one of the city's many universities. The tattoos at this studio are reasonably priced, costing between 200,000Rp and $500,000 \mathrm{Rp}$ (US\$19 to US\$47). It is also more representative in terms of the ambivalent attitudes of its tattooists. Unlike Sono, none of them live exclusively from their work. One evening, I recounted that a young student had described his tattoos as a work of 'art'. The tattooist, who I will call Joni, scoffed at the suggestion that his tattoos might be described in this way. Joni explained that he did not think of his work as art. He laughed when he explained that he considered himself not an 'artist' (seniman) but rather a 'handyman' (tukang). ${ }^{5}$ I asked whether being an artist simply meant being better paid. He responded that this was certainly the case, but not all that the difference signified.

Tukang? That's hard work [keras] and poorly paid. We aren't experts [ahli] but selftaught [belajar sendiri]. As an artist you can make your own creations that have style [gaya] and character [karakter]. As a tukang I do whatever people ask me to do, with some modifications.

Tukang do not work full time as tattooists. They often take other jobs, or try to complete their studies in their spare time. Tukang do not understand their work as creative, but rather as a job completed on demand. Rather than emphasise expert knowledge or selfimprovement, kustom tattooing stresses a messiness and openness to interpretation. In the case of kustom tattooing, Joni explained, there is no-one who you would seek out as a 'tattoo expert' [ahli tato]. Joni added: 'Indonesia is no nation of experts. Rather, people teach themselves, it is a nation of people who try something, modifying it as they go. You do it [learn how to tattoo] on your own'. This contrasts with other forms of body modification which rely on expertise to facilitate self-improvement.

Smaller studios staffed by part-time tukang are far more common than studios such as Sono's in Ubud, described in the previous section. For example, while Kampret is considered an excellent tattooist, he also refers to himself as a tukang. His studio 
was neat and tidy, crowded with images, equipment and magazines. Each time I visited I found three or four other people hanging out there, smoking and listening to punk music. Kampret laughed when he told me that he had only started tattooing when friends realised he could draw and asked him to try out tattooing on them. From these humble beginnings, Kampret now makes a reasonable living almost entirely from his practice thanks to a steady stream of young, middle-class customers. He echoed Joni when he suggested that kustom's strength lies in its disavowal of expertise. On my first visit, Kampret showed me the studio, drawing my attention to the customdesigned and built tattoo machines or 'guns' that he makes with friends. They are made of various pieces of scrap metal and other bits and pieces widely available in Yogyakarta. Each of them, he told me, has a specific feel, applicable to a particular genre of tattoo practice. For example, old-school tattoos need particular lines and shapes, and so the particular machine will be made with this in mind.

Kustom tattooists like these customise their guns because they help them to create the kind of tattoos that they want. However, it also allows them to reduce the cost of tattoo equipment and thus to spread the kustom style throughout Indonesia. This ensures that Kampret and others are able to expand a kustom tattoo community through workshops and other events. In this regard, kustom's disavowal of expertise extends to the very equipment used to practice it. According to Kampret, a machine made out of scrap metal is also better because it offers a tool customised for the particular tattooist, as well as a greater ability to modify tattoo designs. Kampret downplayed the considerable expertise involved in both tattoos and equipment despite the fact that he is skilful and well-practised. Both he and other kustom tattooists consider it to be a process of customisation that draws on pre-existing patterns and designs, rather than a practice requiring creative and technical expertise.

The differences between the three tattoo studios introduced in this section reveal the diversity of kustom tattooing. It ranges from full-time endeavours in the rice fields of Ubud to small one-room shops on dusty highways in Java. Tukang like Joni are the most pragmatic of kustom tattooists. Despite being the most politically engaged, the tukang also needs to pay the bills. After all, the most popular requests, Joni conceded, are tattoos that imitate famous media personalities. Tukang are happy to provide tattoos that appeal to a mass audience, revealing how the national media plays a central role in determining aesthetics of self-expression. Despite the commercial and superficial appearance of such tattoos, ideals of rebellion and freedom remain part of the appeal of the practice. However, consumers of tattoos distance themselves from a history of tattooing that labels it criminal and dangerous. Yet, the selection of a tattoo as a medium for self-expression does not represent a desire on the part of the consumer to be disciplined or refined. Even by selecting a media celebrity's tattoo, young middle-class Indonesians disavow dominant cultures of expertise, appropriating transnational images into something which is their own.

While engaging with mass media trends, tattooists and consumers alike retain an ambiguous relationship with the subaltern history of the practice in Indonesia. 
Consumers distance themselves from what they describe as the lower-class connotations of tattooing by drawing on various strategies. I have mentioned one young man who explained that tattoos 'are no longer considered something for people who are bad [jahat] or deliquent [nakal]. They are art'. In the following section I focus on the way that middle-class consumers negotiate tattooing despite its potential negative connotations. In order to do so I describe how women in particular negotiate tattooing as a mode of self-expression, despite the fact that it is considered inappropriate according to dominant understandings of femininity.

\section{'Good Girls Don't Get Tattoos'}

Tattooing is for the most part a masculine domain: most tattooists, and all of those to whom I spoke for this research, are men. I have described how tattoos have been recuperated into consumerist middle-class culture. Growing numbers of consumers of kustom are transforming it into a means for expressing individual identity rather than expressing membership of a broader community. However, while the tattoo has become tied to self-expression within a certain milieu, its unsavoury connotations remain close to the surface. This is experienced acutely by women.

Perspectives on the gendered aspects of self-expression were revealed most evidently during ngobrol (hanging out), when tattooists consulted with potential clients. I noted that the advice offered by the predominantly male tattooists was different for men and for women. In fact, tattooists frequently advised women that they should not get a tattoo at all. On one occasion, I observed the wife of a tattooist-who specialises in tattoo removal-issue stern advice to a woman in her mid-thirties. She advised her that tattoos are socially inappropriate for respectable girls. 'Have you ever seen a married woman $[i b u]$ with a tattoo?' she asked, prompting laughter. She delivers such advice, she later explained to me, out of necessity for the Indonesian cultural context. This was despite the fact that she herself is a married mother and had many visible tattoos.

Tattoo studios also provided extensive advice to women about the placement of tattoos. One piece of advice given to women was to avoid tattooing names of husbands or boyfriends given the possibility of a breakup or divorce later on. This appears to yield to Indonesia's firm state laws and social conventions regarding marriage and family, and women's perceived role as a responsible 'housewife' (Suryakusuma 1996). The blunt admission of the possibility of divorce, however, shows that tattooists understand women to aspire to relationships based on love and choice, rather than familial responsibility. In this case, the tattoo studio stressed that women should avoid visible placements such as the collarbone or hands. This meant that even with tattoos it would be possible to accommodate clothing such as the quintessential women's dress, the kebaya, worn at weddings and other family and social gatherings. Placing a tattoo on a part of the body which is revealed by wearing these types of clothing may dangerously expose a tattoo to kin. The ideal placement for women, tattooists suggested, is the lower back and upper leg. These are rarely displayed and can be 
covered up if required. In this way, middle-class women navigate gendered social conventions such as marriage while maintaining their desire for tattoos.

In the end, the consumer I observed decided to display her first tattoo visibly on her collarbone. The tattoo studio staff waited for hours while she made this decision, apparently unnerved. She explained her decision with reference to her bold personality: 'What is the point if I am just going to hide it!' The tattooist sighed, but smiled and replied, 'It's your body'. Tattooists told me that this was rare. In contrast, most middleclass female consumers decided to tattoo parts of the body that could be covered up. While in the United States, women's motivations for getting tattoos are often concerned with reclaiming their bodies (DeMello 2000, 173), in Indonesia advice given to female customers reveals an overall observance of dominant national ideologies of gender and kinship. However, women negotiate these norms in order to express their identity. Tattoos on a woman's upper leg, for instance, are often large and frequently depict portraits or names of family members, often mothers or children. The strategic placement of tattoos allows women to conceal them in the presence of extended family or when returning to their hometown. Tattooing reflects shifts in understandings of femininity, revealing how new possibilities for self-expression intersect with existing ideals about gender and class.

Advice offered to female consumers of tattoos reveals that it is possible to be both a good mother and citizen and have tattoos, so long as the tattoo is located somewhere that can be concealed and revealed according to the setting. Following Boellstorff $(2005,205)$, such feminine subjectivities might be described in terms of what he calls 'archipelagic', in that 'their authenticity does not require renouncing other subjectivities'. Such identities are negotiated strategically, with different aspects of the self revealed in different places and in the context of different social groups. As part of a masculine, urban form of consumer culture, popular practices of tattooing are centred on self-expression. However, tattooists and consumers negotiate the practice in line with the unique cultural context of post-authoritarian Indonesia. Thus, gendered negotiations in the tattoo studio over how and in what ways tattoos are suitable for middle-class consumers reveal that even as they are recuperated into consumer culture, they remain linked to broader social prohibitions and collective historical memories about the practice.

\section{Conclusion}

Huhum stressed that even though tattooing appeared to be entering mainstream middle-class culture, it could be set apart from other practices linking consumption and self-expression. 'We are not a nation of experts [tidak negara ahli], you know', he said, describing the widespread adeptness at customisation in Indonesia as a national trait. This suggests that the contingency and individuality that kustom makes possible is its appeal: it requires 'creation, imagination and innovation ... to introduce us to our own identity. There isn't anything wrong with calling this space kustom culture' (Magic Ink 2013). While there is now a large kustom scene in Yogyakarta and other 
cities, the practice remains ambiguously located: it is both unrecognised and unregulated by anyone but its own practitioners. It is precisely the absence of a claim to expertise that is its allure, a characteristic which is inseparable from its national history as a practice subjected to a high degree of stigma. However, middle-class consumers of kustom tattoos insist on distancing themselves from the kinds of tattoo studios and communities of the urban poor most violently affected by the 'mysterious killings' of the 1980s. They negotiate this history by referring to tattooing as an individualistic and artistic form of self-expression (mostly in the case of men), or by placing tattoos in locations that can be covered (in the case of women).

This article has outlined how Indonesian tattooists draw on transnational youth culture to craft a distinctive style of self-expression in post-authoritarian Indonesia. While consumers draw on the word 'art' to describe their tattoos, and hence distance themselves from any pejorative meanings, tattooists prefer to refer to themselves as 'handymen'. By this they mean that they are not experts but self-taught. In doing so, kustom tattooists help consumers express their individual identity: in the process they do not create something new, but rather 'modify' and 'customise' existing images from various times and places. Kustom tattooing hints at complex transformations at the intersection of gender, class and ethnicity as they relate to consumption in contemporary Indonesia. Gender is particularly central to this transformation, given both the masculine domain of tattooing and the apparent appeal of tattooing to women. Further research is required to articulate how tattooing overlaps with or differs from other dimensions of middle-class culture and identity also related to gender and the body (Brenner 1996; Jones 2010a, 2010b).

By modifying the bodies of middle-class Indonesians, kustom tattooists reflect a 'system of meanings and values' which form a 'microcosm of ... the body politic' (Turner 2012, 491). Indeed, kustom incorporates an unruly range of ideas from settings as diverse as a growing mass media; a body-centred consumer capitalist economy; a national aesthetic of DIY; subaltern histories; and a category drawn from a 'hipster' culture with an imagined America at its heart. Holding these ideas together is a desire for self-expression and bodily autonomy, one which negotiates state ideals and kinship obligations. In this regard, kustom tattooing is a fitting metaphor for self-expression in post-authoritarian Indonesia, where emergent forms of middle-class consumption take place in the shadow of recent histories of state repression and violence.

\section{Acknowledgements}

Preliminary research for this article was conducted as a Masters-level research project at the Monash Asia Institute at Monash University. I acknowledge the generous comments of Dr Claudia Liebelt in the early stages of writing. I am very grateful to Dr Philip Taylor for his constructive engagement with an earlier version of this article, as well as the detailed insights of two anonymous reviewers. Finally, I am especially grateful to Huhum in Yogyakarta for his guidance and time in introducing me to Indonesian kustom. 


\section{Notes}

[1] The appointment of businesswoman Susi Pudjiastuti as Minister of Marine Affairs and Fisheries (and importantly her tattoos) received a great deal of national media attention in October 2014.

[2] This is an estimate based on the size of the Indonesian population and information provided to me by kustom tattooists who travel frequently throughout the region. There is very little research about mainstream and middle-class tattoo practices in Southeast Asia with which to base a comparison.

[3] In my field site kustom refers to 'customised' and has been appropriated into Indonesian from its counterpart 'kustom' which originated in white working-class male culture of the United States, mostly in the form of 'customising' or modifying ready-made cars and motorbikes (DeWitt 2002). Despite this, kustom tattooists and enthusiasts describe 'kustom' as appropriate to Indonesian culture (see Magic Ink 2013), reminiscent of Boellstorffs (2005) description of 'dubbing culture'.

[4] Li (2001) writes that the 'noble savage' was not yet a popular trope immediately following the fall of authoritarian dictator Suharto, and my sense is that this remains the case. Tattoos based on indigenous peoples' designs, motifs or practices were usually more popular among foreigners (frequently Westerners) or Indonesians who had spent time abroad.

[5] Tukang is an interesting Indonesian word that refers to someone who is self-trained, bringing to mind the French term bricoleur (Lévi-Strauss 1966; see Luvaas 2010 for a novel use of the concept in the Indonesian context). Indonesians tend not to call a formally trained and accredited 'plumber' or 'electrician' for help, but rather, a tukang listrik (electrical handyman) who is considered to be self-trained, uses improvisation and charges at a much lower rate.

\section{References}

Baulch, E. 2007. Making Scenes: Reggae, Punk, and Death Metal in 1990s Bali. Durham: Duke University Press.

Boellstorff, T. 2005. The Gay Archipelago: Sexuality and Nation in Indonesia. Princeton: Princeton University Press.

Boellstorff, T. 2007. A Coincidence of Desires: Anthropology, Queer Studies, Indonesia. Durham: Duke University Press.

Brenner, S. 1996. "Reconstructing Self and Society: Javanese Muslim Women and "The Veil"." American Ethnologist 23 (4): 673-697.

Brenner, S. 2011. "Private Moralities in the Public Sphere: Democratization, Islam, and Gender in Indonesia." American Anthropologist 113 (3): 478-490.

DeMello, M. 2000. Bodies of Inscription: A Cultural History of the Modern Tattoo Community. Durham: Duke University Press.

DeWitt, J. 2002. Cool Cars, High Art: The Rise of Kustom Kulture. Jackson: University Press of Mississippi.

Heryanto, A. 1999. “The Years of Living Luxuriously: Identity Politics of Indonesia’s New Rich.” In Culture and Privilege in Capitalist Asia, edited by Michael Pinches, 159-187. London: Routledge.

Heryanto, A. 2008. Popular Culture in Indonesia: Fluid Identities in Post-Authoritarian Politics. London: Routledge.

Jones, C. 2010a. "Images of Desire: Creating Virtue and Value in an Indonesian Islamic Lifestyle Magazine.” Journal of Middle East Women's Studies 6 (3): 91-117. 
Jones, C. 2010b. "Better Women: The Cultural Politics of Gendered Expertise in Indonesia." American Anthropologist 112 (2): 270-282.

Lévi-Strauss, C. 1966. “The Science of the Concrete.” In The Savage Mind, 1-33. Chicago: University of Chicago Press.

Li, T. M. 2001. "Masyarakat Adat, Difference, and the Limits of Recognition in Indonesia's Forest Zone." Modern Asian Studies 35: 645-676.

Luvaas, B. 2010. 'Designer Vandalism: Indonesian Indie Fashion and the Cultural Practice of Cut 'N' Paste." Visual Anthropology Review 26 (1): 1-16.

Magic Ink. 2011a. Artist Profile Freddy Mock, vol. 15.

Magic Ink. 2011b. Indonesia Tato Setelah 1998, vol. 19.

Magic Ink. 2012. Kustom Fest, vol. 33.

Magic Ink. 2013. Kustom Kulture, vol. 36.

Martin-Iverson, S. 2014. "Bandung Lautan Hardcore: Territorialisation and Deterritorialisation in an Indonesian Hardcore Punk Scene.” Inter-Asia Cultural Studies 15 (4): 532-552.

Rosenblatt, D. 1997. "The Antisocial Skin: Structure, Resistance, and 'Modern Primitive' Adornment in the United States." Cultural Anthropology 12 (3): 287-334.

Siegel, J. T. 1998. A New Criminal Type in Jakarta: Counter-Revolution Today. Durham: Duke University Press.

Strassler, K. 2010. Refracted Visions: Popular Photography and National Modernity in Java. Durham: Duke University Press.

Suryakusuma, J. I. 1996. "The State and Sexuality in New Order Indonesia." In Fantasizing the Feminine in Indonesia, edited by Laurie J. Sears, 92-119. Durham: Duke University Press.

Turner, T. S. 2012. “The Social Skin." HAU: Journal of Ethnographic Theory 2 (2): 486-504.

van der Kroef, J. M. 1985. "'Petrus': Patterns of Prophylactic Murder in Indonesia." Asian Survey 25 (7): 745-759. 